\title{
Bismuth embedded silica nanoparticles loaded with autophagy suppressant to promote photothermal therapy
}

Tong Chen ${ }^{\dagger, \infty}$, Dong Cen ${ }^{\ddagger,}$, Zhaohui Ren ${ }^{\dagger}$, Yifan Wang, Xiujun Cai ${ }^{\ddagger}$, Jie Huang ${ }^{\ddagger}$, Lucy Di Silvio, ${ }^{\$}$ Xiang Li ${ }^{\dagger} *$, Gaorong Han ${ }^{\dagger}$

$\dagger$ State Key Laboratory of Silicon Materials, School of Materials Science and Engineering, Zhejiang University, Hangzhou, Zhejiang 310027, P. R. China

$¥$ Key Laboratory of Endoscopic Technique Research of Zhejiang Province, Sir Run Run Shaw Hospital, Zhejiang University, Hangzhou 215123, P. R. China

" Department of Mechanical Engineering, UCL, Torrington Place, London, UK

\$ Faculty of Dentistry, Oral \& Craniofacial Sciences. King’s College London, UK

* Corresponding Author: xiang.li@zju.edu.cn

${ }^{\infty}$ Authors with equal contribution

KEYWORDS: bismuth nanocrystal, mesoporous silica nanoparticles, photothermal therapy, autophagy suppression

Abstract: An unpredicted side effect of photothermal therapy (PTT) is agitated by hyperthermia which results in damage to healthy tissue. Developing PTT platforms, enabling effective tumor ablation under mild irradiation conditions, is of wide interest, but challenging. Here, we investigated bismuth crystals embedded silica $\left(\mathrm{Bi} @ \mathrm{SiO}_{2}\right)$ nanoparticles, loaded with an autophagy inhibitor (chloroquine, CQ). It was found that $\mathrm{SiO}_{2}$ effectively prevented the oxidization of $\mathrm{Bi}$ nanocrystals in the physiological environment and could serve as a scatter layer to improve NIR absorption, enabling a high photothermal conversion efficiency $(\sim 43 \%)$ and excellent photostability. Furthermore, the findings indicated that CQ molecules, delivered intracellularly by the particles, significantly weakened the degradation of autolysosomes by lysosome within the tumor cells, thus inducing suppression effect to autophagy and resistance to photothermia. Both in vitro and in vivo anti-tumor effects were consequently promoted owing to the combined effects enabled by $\mathrm{Bi} @ \mathrm{SiO}_{2}-\mathrm{CQ}$ nanoparticles under mild NIR irradiation conditions. This study demonstrates a potential new PTT platform with superior therapeutic efficacy. 


\section{INTRODUCTION}

Photothermal therapy (PTT) is an effective approach for cancer treatment, by converting radiation to heat for tumor ablation via light-absorbing nanomaterials $[1,2]$. PTT triggered by NIR irradiation presents a number of superior characteristics, including minimal invasiveness, certain tumor specificity, operational controllability and so on $[3,4]$. However, it's been reported that tumor cells present resistance to photothermia by different degrees, inducing the ineffective ablation of tumor [5]. This resistance mainly originates from an intracellular mechanism, so-called 'autophagy' [6]. Autophagy is a cellular pathway which degrades the damaged organelles, aged proteins, and other components, and recycles to provide cells with the nutrients to renew themselves [6-8]. In addition, autophagy also plays a crucial role in assisting cells to resist cellular stresses and diverse therapeutics [9-12]. Cellular damage caused by heating can be repaired and reversed by the autophagy process, resulting in an incomplete cell necrosis $[13,14]$. To overcome such therapeutic resistance, more harsh conditions (e.g. high temperature or prolonged irradiation time) were selected during PTT, which can consequently result in unexpected damage to noncancerous tissue nearby [15-18]. Hence, the development of an advanced PTT platform, enabling effective autophagy suppression, is highly attractive and advantageous to achieve a more targeted and specific for the tumor destruction

An optimal PTT system should ideally possess a strong NIR absorbance, high photothermal conversion efficiency and low cytotoxicity [19, 20]. A variety of PTT agents, such as Au-based nanomaterials [21], carbon nanomaterials [22], black phosphorous [19,23] and metal chalcogenides [24] have been extensively investigated. Comparing to the current systems, bismuth (Bi), known as 'green metal', is a nontoxic and abundant metallic material [25], and Bi-based materials (i.e. $\mathrm{Bi}$ [26], $\mathrm{Bi}_{2} \mathrm{~S}_{3}$ [27] and $\mathrm{Bi}_{2} \mathrm{Se}_{3}$ [28]) have been developed as potential PTT agents. It presents strong absorption in NIR region and photothermal conversion efficiency [26]. The atomic number of bismuth element is high $(Z=83)$, enabling it to potentially serve as a contrast agent for 
computed tomography (CT) imaging [29]. It has been recently reported that bismuth nanoparticles are highly reactive in the physiological environment, tend to oxidatively decompose to bismuth (III) species [30]. Even with polymeric coating as the surface protection, this oxidation reaction of Bi nanospheres cannot be prevented [31]. As a consequence, the photoabsorption properties of $\mathrm{Bi}$ particles in the NIR region is diminished and no photothermal properties can be achieved for PTT cancer treatment [31]. Hence, an effective methodology for constructing Bi-based PTT systems, with fine microstructures and strong NIR photothermal conversion, is still lacking.

Herein, a multifunctional Bi-based therapeutic system, endowed with both high photothermal conversion efficiency and autophagy suppression, was investigated for effective PTT at a mild irradiation condition. In this system, fine Bi nanocrystals were formed and entrapped within the pores of mesoporous silica nanoparticles ( $\left.\mathrm{Bi} @ \mathrm{SiO}_{2}\right)$, enabling the effective protection for Bi element from oxidation and high photothermal conversion efficiency (Fig. 1). In addition, an autophagy inhibitor, chloroquine (CQ), was loaded on the $\mathrm{Bi} @ \mathrm{SiO}_{2}$ particles $\left(\mathrm{Bi} @ \mathrm{SiO}_{2}-\mathrm{CQ}\right)$ and delivered intracellularly. It was shown that the effective suppression of autophagy was achieved by disturbing the lysosome and weakening the degradation of autolysosomes induced by CQ molecules released within cancer cells $[32,33]$. Combining the strong photothermal properties and autophagy suppression to cancer cells, both in vitro and in vivo anticancer effects were promoted by $\mathrm{Bi} @ \mathrm{SiO}_{2}-\mathrm{CQ}$ system under a mild NIR irradiation. This study therefore offer another potential platform for PTT cancer treatment with superior efficacy.

\section{EXPERIMENTAL SECTION}

2.1. Chemical and Reagents. Chemicals used were Hexadecyl trimethyl ammonium bromide $(\mathrm{CTAB})$, poly(vinylpyrrolidone) $\left(\mathrm{PVP}\right.$, molecular weight $\left.=58000 \mathrm{~g} \mathrm{~mol}^{-1}\right)$ and chloroquine diphosphate (Aladdin Reagents, Shanghai, China). Tetraethyl orthosilicate (TEOS) (Sigma-Aldrich). Sodium borohydride $\left(\mathrm{NaBH}_{4}, 98 \%\right)$, ammonium hydroxide, methanol, ethyl acetate and bismuth nitrate pentahydrate $\left(\mathrm{Bi}\left(\mathrm{NO}_{3}\right)_{3} \cdot 5 \mathrm{H}_{2} \mathrm{O}, 99 \%\right)$ (Sinopharm Chemical Reagent Co. Ltd). The cell counting kit-8 (CCK-8) and 
LysoTracker Red were purchased from Beyotime. All the chemicals above were used directly without further purification.

2.2. Characterizations. Scanning electron microscopy (SEM) images were taken by a scanning electron microscope (SU-70, Hitachi, Japan) and Transmission electron microscopy (TEM) images were taken by a transmission electron microscope (HT7700, HITACHI, Japan). The elemental mapping was obtained by a JEOL electron microscope (JEM-2100, JEOL, Japan). The phase identification was investigated by X-ray diffraction instrument (XRD, X' pert PRO MPD, Netherlands) with $\mathrm{Cu} \mathrm{K} \alpha$ radiation $(\lambda=0.154 \mathrm{~nm})$ and operating at $40 \mathrm{kV}$ and $40 \mathrm{~mA}$. The examination of X-ray photoelectron spectroscopy (XPS) was carried out using VG ESCALAB MKII spectrometer. The UV-Vis spectra were recorded by a spectrophotometer (UV2600, Shimadzu, Japan). The dynamic light scattering (DLS) zeta potential and size distribution were measured on a Malvern zetasizer (nano-ZS90, UK). The Bi concentration in $\mathrm{Bi} @ \mathrm{SiO}_{2}$ was quantified by the inductively-coupled plasma mass spectrometry (ICP-MS, Aurora M90, Analytik Jena).

\subsection{Synthesis of $\mathrm{SiO}_{2}, \mathrm{Bi} @ \mathrm{SiO}_{2}$ Nanoparticles and PVP-Bi Nanodots. $\mathrm{SiO}_{2}$} nanoparticles were synthesized following the method reported previously [34, 35]. Briefly, $200 \mathrm{mg}$ CTAB was dissolved in $10 \mathrm{~mL}$ deionized water and stirred for 30 minutes. The resulting solution was added to a mixed solvent of $95 \mathrm{~mL}$ deionized water, $20 \mathrm{~mL}$ ethyl acetate, $5 \mathrm{~mL}$ methanol, and $3 \mathrm{~mL}$ ammonium hydroxide under stirring. Subsequently, $0.5 \mathrm{~mL}$ TEOS was added to the solution above and stirred for 12 hours at room temperature. Finally, the $\mathrm{SiO}_{2}$ precipitate prepared was washed for three times with ethanol and annealed at $550{ }^{\circ} \mathrm{C}$ for $3 \mathrm{~h}$ in air.

$30 \mathrm{mg} \mathrm{SiO} 2$ particles were dispersed in $15 \mathrm{~mL}$ deionized water. $300 \mathrm{mg}$ PVP and 100 $\mathrm{mg} \mathrm{Bi}\left(\mathrm{NO}_{3}\right)_{3} \cdot 5 \mathrm{H}_{2} \mathrm{O}$ were dissolved in $10 \mathrm{~mL}$ ethanol at $55^{\circ} \mathrm{C}$. The solution was then added to $\mathrm{SiO}_{2}$ aqueous solution, and the mixture was sonicated for 30 minutes. Subsequently, $10 \mathrm{~mL}$ ice-cold $0.01 \mathrm{M} \mathrm{NaBH}_{4}$ was added and stirred for 1 minute, 
resulting in a black coloured solution. The precipitate was then centrifuged and washed with deionized water, and re-dispersed in deionized water for further use.

The PVP-Bi nanodots were synthesized as previously described [26]. Briefly, $300 \mathrm{mg}$ of PVP and $100 \mathrm{mg}$ of $\mathrm{Bi}\left(\mathrm{NO}_{3}\right)_{3} \cdot 5 \mathrm{H}_{2} \mathrm{O}$ were dissolved in $10 \mathrm{~mL}$ ethanol and heated at $55{ }^{\circ} \mathrm{C}$ until dissolved. Then, $10 \mathrm{~mL}$ of ice-cold $\mathrm{NaBH}_{4}(0.01 \mathrm{M})$ was added and stirred for $1 \mathrm{~min}$. The products were collected by centrifugation, washed with deionized water, and then re-dispersed in deionized water.

2.4. Loading of CQ. $0.5 \mathrm{~mL}$ CQ water solution $(20 \mathrm{mg} / \mathrm{mL})$ was added to $\mathrm{Bi} @ \mathrm{SiO}_{2}$ $(1 \mathrm{mg} / \mathrm{mL})$ aqueous solution. The mixture was stirred in the dark for $24 \mathrm{~h}$ at room temperature. Subsequently, the $\mathrm{Bi} @ \mathrm{SiO}_{2}-\mathrm{CQ}$ were centrifuged at $10000 \mathrm{rpm}$ for 10 minutes and washed three times with deionized water to remove the excessive CQ attached on the surface of particles. The washing solution was collected to calculate the drug loading ratio. According to the absorbance of CQ solutions at $\sim 344 \mathrm{~nm}$, the calibration curve of CQ concentration was obtained. Then, the washing solution was recorded by the UV-Vis spectrometer and the drug loading ratio of CQ was estimated according to the calibration curve.

2.5. Photothermal Effect. $2 \mathrm{~mL} \mathrm{Bi@SiO} 2$ aqueous solution $(0,25,50,100,200,400$ $\mu \mathrm{g} / \mathrm{mL})$ was irradiated by $808 \mathrm{~nm}$ laser $\left(1.0 \mathrm{~W} \mathrm{~cm}^{-2}, 10 \mathrm{~min}\right)$. The temperature was recorded every $10 \mathrm{~s}$ using an infrared thermal imaging camera (E60, FLIR, USA). To calculate the photothermal conversion efficiency $(\eta), 2$ mL Bi@ $\mathrm{SiO}_{2}$ aqueous solution $(400 \mu \mathrm{g} / \mathrm{mL})$ was irradiated by $808 \mathrm{~nm}$ laser until the temperature was steady. The laser was then switched off, to allow cooling of solution with 10 second interval temperature was recorded.

2.6. In vitro Cytotoxicity Assay. Murine 4T1 breast cancer cells were seeded in 96well plates at a density of $2 \times 10^{4}$ cells per well and cultured at $37{ }^{\circ} \mathrm{C}$ and $5 \% \mathrm{CO}_{2}$ for 12 h. Then, $\mathrm{Bi} @ \mathrm{SiO}_{2}$ solutions with different concentration $(0,25,50,100,200$ and $400 \mu \mathrm{g} / \mathrm{mL}$ ) were added into the well and co-incubated with cells for $12 \mathrm{~h}$ and $24 \mathrm{~h}$. 
After removing the medium, $10 \mu \mathrm{L}$ cell counting kit-8 (CCK-8) in $100 \mu \mathrm{L}$ DMEM (containing 10\% FBS) was added to each well and incubated for further1 h. Finally, the absorbance of each well at $450 \mathrm{~nm}$ was measured by a microplate reader (Infinite F50, Tecan, Switzerland).

2.7. In vitro Therapy Evaluation. Murine $4 \mathrm{~T} 1$ breast cancer cells were seeded in 96-well plates at a density of $2 \times 10^{4}$ cells per well and cultured at $37{ }^{\circ} \mathrm{C}$ and $5 \% \mathrm{CO}_{2}$ for 12h. The CQ $(26.6 \mu \mathrm{g} / \mathrm{mL}), \mathrm{Bi} @ \mathrm{SiO}_{2}(200 \mu \mathrm{g} / \mathrm{mL})$ and $\mathrm{Bi} @ \mathrm{SiO}_{2}-\mathrm{CQ}(200 \mu \mathrm{g} / \mathrm{mL}$ for $\mathrm{Bi} @ \mathrm{SiO}_{2}, 26.6 \mu \mathrm{g} / \mathrm{mL}$ for CQ) was added to the cells and incubated for $15 \mathrm{~h}$, followed with or without $808 \mathrm{~nm}$ irradiation $\left(1.0 \mathrm{~W} \mathrm{~cm}^{-2}, 5 \mathrm{~min}\right)$. The cell viability was determined by a CCK-8 assay.

The assessment for autophagy inhibition-sensitized photothermal therapy effect in vitro was further pursued. 4T1 cells were seeded in 96-well plates at a density of $2 \times 10^{4}$ cells per well. Subsequently, solutions of $\mathrm{Bi} @ \mathrm{SiO}_{2}$ and $\mathrm{Bi} @ \mathrm{SiO}_{2}-\mathrm{CQ}$ where added at varying concentrations $\left(0,25,50,100,200,400 \mu \mathrm{g} / \mathrm{mL}\right.$ for $\mathrm{Bi} @ \mathrm{SiO}_{2}, 0,3.325,6.65$, 13.3, 26.6, $53.2 \mu \mathrm{g} / \mathrm{mL}$ for CQ) were incubated with cells for $15 \mathrm{~h}$, respectively, followed by $808 \mathrm{~nm}$ irradiation $\left(1.0 \mathrm{~W} \mathrm{~cm}^{-2}, 5 \mathrm{~min}\right)$. The cell viability was examined by a CCk-8 assay.

The effect of autophagy inhibition-sensitized photothermal therapy was examined in vitro using a different irradiation time, 4T1 cells were seeded in 96-well plates at a density of $2 \times 10^{4}$ cells per well. Bi@SiO $2(200 \mu \mathrm{g} / \mathrm{mL})$ and $\mathrm{Bi} @ \mathrm{SiO}_{2}-\mathrm{CQ}(200 \mu \mathrm{g} / \mathrm{mL}$ for $\mathrm{Bi} @ \mathrm{SiO}_{2}, 26.6 \mu \mathrm{g} / \mathrm{mL}$ for CQ) were incubated with cells for $15 \mathrm{~h}$, followed by 808 $\mathrm{nm}$ irradiation $\left(1.0 \mathrm{~W} \mathrm{~cm}^{-2}\right)$ for different time periods $(0,1,2,3,4,5 \mathrm{~min})$. The cell viability was determined by a CCk-8 assay.

2.8. Western Blot Assay. $4 \mathrm{~T} 1$ cells were seeded in 6 -well plate at a density of $4 \times 10^{5}$ cells per well. The cells were incubated with samples for $15 \mathrm{~h}$, followed with $808 \mathrm{~nm}$ irradiation $\left(1.0 \mathrm{~W} \mathrm{~cm}^{-2}, 5 \mathrm{~min}\right)$. The cells were lysed with lysis buffer and the supernatant was harvested after centrifugation. After adding the SDS buffer, the 
samples were boiled for $5 \mathrm{~min}$ and subsequently separated in 12\% SDS-PAGE and transferred to a PVDF membrane. The PVDF membrane was blocked with a blocking buffer for $20 \mathrm{~min}$, washed with scrubbing solution for three times, incubated with a primary antibody (anti-LC3), anti-Actin antibody for $15 \mathrm{~h}$ at $4{ }^{\circ} \mathrm{C}$, and further incubated with a secondary antibody for 1h. Finally, the bands were shot by Bio-Rad chemoluminescence imaging system.

2.9. LysoTracker Red Staining Assay. Solutions containing CQ (26.6 $\mu \mathrm{g} / \mathrm{mL})$, $\mathrm{Bi} @ \mathrm{SiO}_{2}(200 \mu \mathrm{g} / \mathrm{mL})$ and $\mathrm{Bi} @ \mathrm{SiO}_{2}-\mathrm{CQ}\left(200 \mu \mathrm{g} / \mathrm{mL}\right.$ for $\mathrm{Bi} @ \mathrm{SiO}_{2}, 26.6 \mu \mathrm{g} / \mathrm{mL}$ for CQ) were incubated with 4T1 cells, respectively, for $15 \mathrm{~h}$, followed by $808 \mathrm{~nm}$ irradiation $\left(1.0 \mathrm{~W} \mathrm{~cm}^{-2}, 5 \mathrm{~min}\right)$. The $4 \mathrm{~T} 1$ cells were then stained with DAPI and LysoTracker red at $37^{\circ} \mathrm{C}$, The cells were observed by positive-placed two-photon confocal microscope (Olympus BX61, Japan).

\subsection{In vivo Autophagy Inhibition-Sensitized Photothermal Therapy Effect. The} animal model used was Female BALB/c mice injected 4T1 cells. When the tumor volumes had reached approximately $70-100 \mathrm{~mm}^{3}$, the mice were ready for the experimental procedure used. The mice were divided into six groups $(5$ mice per group): (1) control; (2) NIR irradiation only (808 nm); (3) CQ (4.4 mg kg-1, $50 \mu \mathrm{L})$ injection only; (4) $\mathrm{Bi} @ \mathrm{SiO}_{2}-\mathrm{CQ}$ nanoparticles (33.3 mg kg-1 for $\mathrm{Bi} @ \mathrm{SiO}_{2}, 4.4$ mg kg-1 for $\mathrm{CQ}, 50 \mu \mathrm{L}$ ) injection only; (5) $\mathrm{Bi} @ \mathrm{SiO}_{2}$ nanoparticles $\left(33.3 \mathrm{mg} \mathrm{kg}^{-1}\right)$ plus $808 \mathrm{~nm}$ laser; (6) $\mathrm{Bi} @ \mathrm{SiO}_{2}-\mathrm{CQ}$ nanoparticles (33.3 mg kg-1 for $\mathrm{Bi} @ \mathrm{SiO}_{2}, 4.4$ mg kg${ }^{-1}$ for $\mathrm{CQ}$, $50 \mu \mathrm{L})$ plus $808 \mathrm{~nm}$ laser. After $10 \mathrm{~min}$, the mice were irradiated with $808 \mathrm{~nm}$ laser $(1.0$ $\left.\mathrm{W} \mathrm{cm}{ }^{-2}, 7 \mathrm{~min}\right)$. The temperature of tumor was recorded by an infrared thermal imaging camera. During the experiments, the body weights and the tumor size of the mice were measured using an electronic balance and a digital caliper every two days. The tumor volume is width $2 \times$ length / 2 .

2.11. Histology Analysis. The tumors from all groups were harvested after $24 \mathrm{~h}$ and fixed using 4\% neutral buffered formalin, then, sliced, stained and observed under an fluorescence microscope. 
2.12. Statistical Analysis. The data were analyzed by Student's-tests with a setting significance of $\mathrm{p}<0.01(* *)$ and $\mathrm{p}<0.001(* * *)$.

\section{RESULTS AND DISCUSSION}

Synthesis and Characteristics of $\mathbf{B i @ S i O} 2-\mathbf{C Q}$. The formation of $\mathrm{Bi} @ \mathrm{SiO}_{2}-\mathrm{CQ}$ nanoparticles was demonstrated in Fig. 2a. The $\mathrm{SiO}_{2}$ nanoparticles prepared were of uniform morphology with an average diameter of $\sim 160 \mathrm{~nm}$. The pores at the surface of particles were $\sim 6 \mathrm{~nm}$ in dimension (Fig. $2 \mathrm{~b}$ and c). When $\mathrm{SiO}_{2}$ nanoparticles were immersed in $\mathrm{Bi}\left(\mathrm{NO}_{3}\right)_{3} \cdot 5 \mathrm{H}_{2} \mathrm{O}$ solution containing PVP as the surfactant, $\mathrm{Bi}^{3+}$ ions and PVP molecules diffuse into the pores of nanoparticles driven by the capillary effect. When $\mathrm{NaBH}_{4}$ solution was added as the reductant, the $\mathrm{Bi}^{3+}$ ions were reduced to form fine crystals within the pores. The morphology of the silica particles was observed to have a rough surface, and when observed under TEM presented as dark particles (Fig. $2 \mathrm{~d}$ and e). The elemental mapping of $\mathrm{Bi} @ \mathrm{SiO}_{2}$ nanoparticles confirmed that high content of $\mathrm{Bi}$, approximately $\sim 7 \% \mathrm{wt}$ as quantified by the inductively-coupled plasma mass spectrometry (ICP), were presents in the nanoparticles in addition to Si and $\mathrm{O}$ elements (Fig. 2f). The XRD pattern of $\mathrm{Bi} @ \mathrm{SiO}_{2}$ nanoparticles showed clear diffraction peaks attributable to rhombohedral phase of Bi (JCPDS No. 44-1246), confirming the crystalline nature of $\mathrm{Bi}$ formed within $\mathrm{SiO}_{2}$ nanoparticles (Fig. 2g). The surface area and pore volume of $\mathrm{Bi} @ \mathrm{SiO}_{2}$ was seen to decrease, reaching $84 \mathrm{~m}^{2} \mathrm{~g}^{-1}$ and $0.21 \mathrm{~cm}^{3} \mathrm{~g}^{-1}$, respectively (Fig. S1, Table S1, Supporting Information). Furthermore, the X-ray photoelectron spectrum of $\mathrm{Bi} @ \mathrm{SiO}_{2}$ revealed the peaks at 156.4 and $161.7 \mathrm{eV}$ corresponding to the metal $\mathrm{Bi} 4 \mathrm{f} 7 / 2$ and $4 \mathrm{f} 5 / 2$ states within silica particles, respectively. No peaks attributable to the $\mathrm{Bi}$ trivalent state were observed, confirming that $\mathrm{Bi}$ nanocrystals formed were not oxidized (Fig. 2h). The as-prepared $\mathrm{Bi} @ \mathrm{SiO}_{2}$ nanoparticles presented good stability and dispersity in water, $0.9 \%$ normal saline (NS), PBS and Dulbecco's modified eagle's medium (DMEM) with an average hydrodynamic diameter of $\sim 190 \mathrm{~nm}$, respectively, paving the way to the further in vitro and in vivo studies (Fig. S2, Table S2, Supporting Information). The stability of 
$\mathrm{Bi} @ \mathrm{SiO}_{2}$ nanoparticles in the aqueous solution is attributed to the PVP molecules induced during in-situ growth reaction of Bi nanocrystals during synthesis. As shown in FTIR spectra (Fig. S3, Supporting Information), $\mathrm{Bi} @ \mathrm{SiO}_{2}$ exhibited a $\mathrm{C}=\mathrm{O}$ stretching vibration peak at $\sim 1653 \mathrm{~cm}^{-1}$, a $-\mathrm{CH}_{2}$ - bending vibration peak at $\sim 1456 \mathrm{~cm}^{-1}$ and a $\mathrm{O}=\mathrm{C}-\mathrm{NH}$ - symmetrical stretching vibration peak at $\sim 1296 \mathrm{~cm}^{-1}$, which are attributed to the characteristic absorption peaks of PVP.

To demonstrate the superior characteristics of $\mathrm{Bi} @ \mathrm{SiO}_{2}$ in preventing the unexpected Bi oxidation, PVP coated Bi nanoparticles (PVP-Bi) was prepared as a comparison following the previous study. As shown in XRD pattern (Fig. 3a), the representative diffraction peaks of Bi rhombohedral phase were marked by yellow triangle, and the representative diffraction peaks of $\mathrm{Bi}_{2} \mathrm{O}_{2} \mathrm{CO}_{3}$ (JCPDS No. 41-1488) were marked by red pentagram. When the PVP-Bi nanoparticles were exposed to air for 4 days, the representative diffraction peaks of $\mathrm{Bi}_{2} \mathrm{O}_{2} \mathrm{CO}_{3}$ where present, confirming the oxidation of PVP-Bi nanoparticles in air, as expected. In contrast, following exposure to air for 4 days, $\mathrm{Bi} @ \mathrm{SiO}_{2}$ nanoparticles maintained their rhombohedral phase, and no other impurities were observed. This phenomenon demonstrates that, in the $\mathrm{Bi} @ \mathrm{SiO}_{2}$ system, the $\mathrm{SiO}_{2}$ matrix can effectively protect the $\mathrm{Bi}$ nanoparticles from oxidation, which is of considerable importance ensuring its photothermal properties.

The $\mathrm{Bi} @ \mathrm{SiO}_{2}$ nanoparticles loaded with CQ molecules via electrostatic interaction can be seen in Fig. 3b. The zeta potential of $\mathrm{SiO}_{2}$ nanoparticles, $\mathrm{Bi} @ \mathrm{SiO}_{2}$ nanoparticles and CQ molecules were $-17.0 \mathrm{mV},+2.7 \mathrm{mV}$ and $-13.7 \mathrm{mV}$, respectively. Following immersion in CQ solution, the zeta potential of particles was o $-9.6 \mathrm{mV}$, and the UVvis absorption showed a clear peak at $\sim 344 \mathrm{~nm}$ which is attributed to CQ absorbance (Fig. 3c). The findings confirmed the successful loading of CQ molecules on the $\mathrm{Bi} @ \mathrm{SiO}_{2}$ nanoparticles, and concurred with the results obtained from Fourier transform infrared spectrometer (FTIR) (Fig. S4, Supporting Information). According to the absorbance and calibration curve of CQ solutions at $344 \mathrm{~nm}$ (Fig. S5, Supporting Information), the loading ratio of CQ was estimated to be $\sim 13.5 \%$. After loading with 
$\mathrm{CQ}$, the $\mathrm{Bi} @ \mathrm{SiO}_{2}-\mathrm{CQ}$ particles maintained excellent stability in water, but the hydrodynamic size increased to $\sim 250 \mathrm{~nm}$ (Fig. 3d and Fig. S6, Supporting Information). The different sizes of $\mathrm{Bi} @ \mathrm{SiO}_{2}$ nanoparticles obtained from the examination using TEM and DLS were attributed to PVP molecules and water shell presented at the surface of nanoparticles.

Photothermal Properties of $\mathrm{Bi} @ \mathrm{SiO}_{2}$ Nanoparticles. The $\mathrm{Bi} @ \mathrm{SiO}_{2}$ nanoparticles synthesized presented the light absorption from ultraviolet to NIR range, and the absorbance at $808 \mathrm{~nm}$ showed a linear relationship with the concentration of nanoparticles (Fig. S7 and S8, Supporting Information). To examine the photothermal properties of $\mathrm{Bi} @ \mathrm{SiO}_{2}$ nanoparticles, aqueous solutions with different particle concentrations $(0,25,50,100,200,400 \mu \mathrm{g} / \mathrm{mL})$ were exposed to the irradiation of 808 $\mathrm{nm}$ laser $\left(1.0 \mathrm{~W} \mathrm{~cm}^{-2}, 10 \mathrm{~min}\right)$. The heating phenomenon was monitored and quantified at each interval of $10 \mathrm{~s}$ using an infrared thermal imaging camera (Fig. 3e and f). The temperature of $\mathrm{Bi} @ \mathrm{SiO}_{2}$ solution $\left(400 \mu \mathrm{g} / \mathrm{mL}, 28 \mu \mathrm{g} / \mathrm{mL}\right.$ for Bi) increased by $\sim 31{ }^{\circ} \mathrm{C}$ after irradiation for $10 \mathrm{~min}$, but the pure water was hardly heated by the irradiation, indicating that $\mathrm{Bi} @ \mathrm{SiO}_{2}$ solution, even with a low concentration, can effectively convert the light into thermal energy in a rapid fashion. It was clear that the heating effect was highly dependent on the particle concentration and the NIR irradiation time. The higher magnitude of laser power density was also found to induce more agitated heating phenomenon, as expected (Fig. S9, Supporting Information).

To calculate the photothermal conversion efficiency ( $\eta), \mathrm{Bi} @ \mathrm{SiO}_{2}$ aqueous solution $(400 \mu \mathrm{g} / \mathrm{mL})$ was irradiated by $808 \mathrm{~nm}$ laser for prolonged period until the temperature reached a steady phase, and cooled down naturally (Fig. 3g). The estimation of the photothermal conversion efficiency was carried out according to the following equations reported in the previous study [36, 37]:

According to $\boldsymbol{t}=-\boldsymbol{\tau}_{\boldsymbol{s}} \ln \boldsymbol{\theta}$ (Fig. S10, Supporting Information), where $\boldsymbol{\theta}=\frac{\Delta \boldsymbol{T}}{\Delta \boldsymbol{T}_{\max }}=$ $\frac{T-T_{\text {surr }}}{T_{\max }-T_{\text {surr }}}$, and $t$ is time, the value of $\tau_{s}$ is obtained. 
According to $\tau_{s}=\frac{\boldsymbol{m}_{d} \boldsymbol{C}_{d}}{\boldsymbol{h} \boldsymbol{S}}$, where $\boldsymbol{m}_{\boldsymbol{d}}$ is the mass of water and $\boldsymbol{C}_{\boldsymbol{d}}$ is the heat capacity of water, the value of $\boldsymbol{h S}$ (h is the heat transfer coefficient and $\mathrm{S}$ is the superficial area) is obtained.

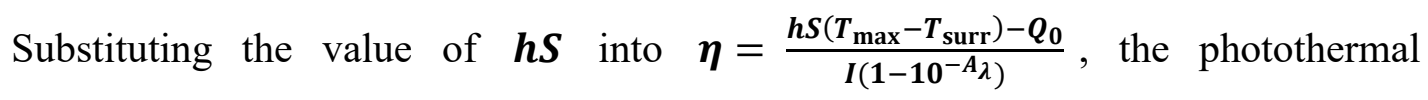
conversion efficiency $(\eta)$ of $\mathrm{Bi} @ \mathrm{SiO}_{2}$ was calculated to be $\sim 4 \%$. It is noteworthy that this value is remarkably higher than current photothermal agents reported in the literature, including gold nanorods $(\sim 21 \%)$ [38], gold nanoparticles $(\sim 11 \%)$ [39], $\mathrm{MoS}_{2}$ nanoflakes ( 27.6\%) [40], Cu9 $\mathrm{S}_{5}$ nanocrystals ( 25.7\%) [41] and Bi nanodots ( 30\%) [26]. This phenomenon may originate from several mechanisms. Firstly, the $\mathrm{SiO}_{2}$ matrix effectively protects the embedded Bi NPs from unexpected oxidation that can induce negative effect to its photothermal properties. In addition, as demonstrated in Fig. 3h, the mesoporous silica shell may serve as a light scattering layer. In consequence, the NIR light is scattered, and the photon path length is thus enlarged, which promotes the absorption of NIR light by the particles [42]. Both mechanisms may contribute to the high photothermal conversion efficiency achieved.

Photostability has been recognized as another crucial factor to evaluate photothermal agents for potential applications in cancer treatment. To this purpose, $\mathrm{Bi} @ \mathrm{SiO}_{2}$ aqueous solution ( $400 \mu \mathrm{g} / \mathrm{mL})$ was exposed to cyclic irradiations using $808 \mathrm{~nm}$ laser $\left(1.0 \mathrm{~W} \mathrm{~cm}^{-}\right.$ ${ }^{2}, 600 \mathrm{~s}$ ). As shown in Fig. 3i, it was found that there was minimal change in peak temperature, and no clear changes in the solution color was observed (Fig. S11, Supporting Information). Both phenomena indicated good photostability of $\mathrm{Bi} @ \mathrm{SiO}_{2}$ nanoparticle, as expected. Overall, the unique photothermal properties that have been observed demonstrate that $\mathrm{Bi} @ \mathrm{SiO}_{2}$ nanoparticles are a promising platform for photothermal therapy.

In addition, the release behavior of $\mathrm{CQ}$ molecules from $\mathrm{Bi} @ \mathrm{SiO}_{2}-\mathrm{CQ}$ under alternating NIR irradiation (on/off) was examined. As expected, the CQ release kinetics was accelerated when irradiated with NIR light $\left(1.0 \mathrm{~W} \mathrm{~cm}^{-2}, 10 \mathrm{~min}\right)$ comparing with 
the group without irradiation. The CQ release behavior slowed down when the NIR laser was turned off, reflecting that the release of CQ could be effectively controlled by NIR light irradiation (Fig. S12, Supporting Information).

In vitro Anti-cancer Properties. The cyto-compatibility of $\mathrm{Bi} @ \mathrm{SiO}_{2}$ nanoparticles in the presence of $4 \mathrm{~T} 1$ breast cancer cells was using the cell counting kit-8. It was found that concentrations of $\mathrm{Bi} @ \mathrm{SiO}_{2}$ solutions ranging from 0 to $400 \mu \mathrm{g} / \mathrm{mL}$ (7\%wt for $\mathrm{Bi}$ ) did not induce cytotoxicity after $24 \mathrm{~h}$ and $48 \mathrm{~h}$ incubation (Fig. 4a). However, when $\mathrm{Bi} @ \mathrm{SiO}_{2}$ solution $(200 \mu \mathrm{g} / \mathrm{mL})$ was exposed to NIR irradiation $\left(1.0 \mathrm{~W} \mathrm{~cm}^{-2}, 5 \mathrm{~min}\right)$, the cell viability was reduced by $\sim 50 \%$ in $24 \mathrm{~h}$. When loaded with CQ, it was observed that $\mathrm{Bi} @ \mathrm{SiO}_{2}-\mathrm{CQ}$ particles induced a significant cell death, reaching $~ 80 \%$ in $24 \mathrm{~h}$, under the same NIR irradiation (Fig. 4b). In addition, $\mathrm{Bi} @ \mathrm{SiO}_{2}$ and $\mathrm{Bi} @ \mathrm{SiO}_{2}-\mathrm{CQ}$ solutions with varied concentrations $(0,25,50,100,200,400 \mu \mathrm{g} / \mathrm{mL}$ corresponding to $0,1.75,3.5,7,14,28 \mu \mathrm{g} / \mathrm{mL}$ for Bi) were incubated with cells with different irradiation time $(0,1,2,3,4,5 \mathrm{~min})$. It was evident that cell viability was reduced with increasing nanoparticle concentrations and prolonged irradiation time, as expected. Even at a low concentration of $\mathrm{Bi}(28 \mu \mathrm{g} / \mathrm{mL})$, the reduction in cell viability was $\sim 70 \%$ in $24 \mathrm{~h}$ for $\mathrm{Bi} @ \mathrm{SiO}_{2}$ solution (Fig. 4c). More importantly, $\mathrm{Bi} @ \mathrm{SiO}_{2}-\mathrm{CQ}$ nanoparticles caused more rapid reduction in cell viability compared to $\mathrm{Bi} @ \mathrm{SiO}_{2}$ nanoparticles with the same concentration and irradiation conditions (Fig. 4c and d). The fluorescence images of live and dead cells verified that the in vitro PTT efficiency of $\mathrm{Bi} @ \mathrm{SiO}_{2}$ nanoparticles was remarkably enhanced owing to the CQ molecules delivered (Fig. 4e).

Mechanisms. To study the enhanced cell killing effect induced by CQ loaded $\mathrm{Bi} @ \mathrm{SiO}_{2}$ nanoparticles, a series of investigations were performed using western blot assay and confocal microscopy. It is known that LC3 protein located on the surface of autophagosome membrane changes into molecular form from LC3 I to LC3 II, upon autophagy [43]. When 4T1 breast cells were cultured in the presence of $\mathrm{Bi} @ \mathrm{SiO}_{2}$ nanoparticles and irradiated by $808 \mathrm{~nm}$ laser, the LC3 II protein increased markedly in the cells, comparing to the cells without NIR irradiation (Fig. 5a and b). This indicated 
that photothermal effect did induce clear cellular autophagy, which agreed with previous findings [12]. Both cell groups, treated with CQ and $\mathrm{Bi} @ \mathrm{SiO}_{2}-\mathrm{CQ}$ under NIR irradiation, presented a high expression of LC3 II protein (Fig. 5c and d). The findings implied that $\mathrm{CQ}$ molecules loaded on the $\mathrm{Bi} @ \mathrm{SiO}_{2}$ nanoparticles did not block the protein conversion from LC3 I to LC3 II. Subsequently, LysoTracker Red was used to stain the acidic vesicles (lysosome) within the cells. After NIR irradiation, Bi@SiO CQ nanoparticles induced significantly enhancement in the accumulation of autophagic vesicles (in red colour) within cells compared with other sample groups (Fig. 5e). In general, autophagy occurs in a series of stages: (1) Intracellular cargoes are engulfed by phagophore, a double-membraned structure; (2) Formation of autophagosome; (3) Autophagosome fusion with lysosomes to generate autolysosome; (4) cargo degradation [44]. Autophagy could remove damaged organelles, resist cellular stresses and induce resistance against therapeutics [12]. In this study, as demonstrated in Fig. $5 f$, the photothermal phenomenon induced high expression of autophagosomes and autolysosomes in tumor cells. CQ molecules delivered by $\mathrm{Bi} @ \mathrm{SiO}_{2}-\mathrm{CQ}$ nanoparticles did not negatively influence the conversion from LC3 I to LC3 II, but suppressed the degradation phenomenon of autolysosomes by lysosome significantly, enabling the strong presence of autophagic vesicles within the cells [12]. The in vitro PTT efficacy was therefore enhanced by a high magnitude for $\mathrm{Bi} @ \mathrm{SiO}_{2}-\mathrm{CQ}$ nanoparticles.

In vivo Study. Balb/c female mice injected with $4 \mathrm{~T} 1$ cells were used as the tumor model. Bi@SiO2-CQ nanoparticles (33.3 mg kg-1 for $\mathrm{Bi} @ \mathrm{SiO}_{2}, 2.331 \mathrm{mg} \mathrm{kg}^{-1}$ for Bi, $4.4 \mathrm{mg} \mathrm{kg}^{-1}$ for $\mathrm{CQ}, 50 \mu \mathrm{L}$ ) were injected into the tumor and irradiated by $808 \mathrm{~nm} \mathrm{NIR}$ $\left(1.0 \mathrm{~W} \mathrm{~cm}^{-2}\right)$ for $7 \mathrm{~min}$. The local heating phenomena at the tumor region was monitored by an IR thermal camera (Fig. 6a). The tumor site after injection was heated up rapidly under NIR irradiation, reaching $\sim 43{ }^{\circ} \mathrm{C}$ in $7 \mathrm{~min}$ (Fig. 6b). This temperature could effectively prevent the excessive damage to healthy tissue while ensuring certain anttumor effect. The results also indicated that $\mathrm{Bi} @ \mathrm{SiO}_{2}$ nanoparticles, even after loading with drug molecules, can potentially serve as a contrast agent for IR photothermal imaging. This unique characteristic potentially enable the real-time monitoring of 
thermal dynamics in PTT practice. Subsequently, the mice were divided into six groups (5 mice per group) as follows: (1) control; (2) NIR irradiation only; (3) CQ with NIR irradiation; (4) $\mathrm{Bi} @ \mathrm{SiO}_{2}-\mathrm{CQ}$; (5) $\mathrm{Bi} @ \mathrm{SiO}_{2}$ with NIR irradiation; (6) $\mathrm{Bi} @ \mathrm{SiO}_{2}-\mathrm{CQ}$ with NIR irradiation. The mice were irradiated with $808 \mathrm{~nm}$ laser $\left(1.0 \mathrm{~W} \mathrm{~cm}^{-2}\right)$ for $7 \mathrm{~min}$ after injecting nanoparticles for $10 \mathrm{~min}$ (group 2, 3, 5 and 6). There were no dramatic changes in the body weight for mice 14 days post the treatment, indicating no clear biotoxicity of samples (Fig. 6c). The tumor volume was measured every 2 days by a digital caliper (Fig. 6d). After the experiments, all the mice were sacrificed, and the tumors were excised and weighed. The average tumor weight of each group after 14 days is shown in Fig. 6e. The photographed tumors are listed in order in Fig. 6f. A representative mouse photograph for each group is shown in Fig. S13 (Supporting Information). The tumors in group 2, 3 and 4 grew rapidly with no clear difference compared to the control group. Following treatment with $\mathrm{Bi} @ \mathrm{SiO}_{2}$ nanoparticles after NIR irradiation (group 5), the tumor growth was suppressed markedly. However, in contrast, sample group $6\left(\mathrm{Bi} @ \mathrm{SiO}_{2}-\mathrm{CQ}\right.$ with NIR irradiation) induced the most significant inhibition effect to tumors growth in mice. The tumor volume dropped rapidly after the treatment and maintained at a low magnitude throughout the study. The tumor tissues harvested for histological examinations by hematoxylin and eosin (H\&E) can be seen in Fig. 6g It was shown that the sample group 6 induced the most severe damage compared to all other groups, as expected. The findings confirmed that $\mathrm{Bi} @ \mathrm{SiO}_{2}$ nanoparticles present great potential as a PTT agent, and the autophagy suppression induced by CQ delivered can remarkably promote the anti-tumor effect in mice. In fact, a number of recent investigations have been endeavored to endow PTT approaches with functional factors which can enable certain autophagy inhibition [4548]. Combining the iron oxide nanoparticle with chloroquine, successfully enhanced the therapeutic efficacy by the inhibition of autophagy suppression [46]. Autophagy inhibitor (CQ and 3-MA) has been utilized in a chemo-PTT synergetic strategy to achieve superior effect against drug-resistant cancer [48]. However, the current studies mainly focused on the direct injection of autophagy inhibitors, inducing lack of control 
for the dosage in following clinical trials. To this end, $\mathrm{Bi} @ \mathrm{SiO}_{2}-\mathrm{CQ}$ nanoparticles fabricated in this study presented superior potential for the PTT approach with milder NIR conditions.

\section{CONCLUSION}

In this study, autophagy inhibitor (CQ) loaded $\mathrm{Bi} @ \mathrm{SiO}_{2}$ nanoparticles were designed and synthesized by in-situ growth of Bi nanocrystals within the mesopores of silica particles. The $\mathrm{SiO}_{2}$ matrix provides an effective protection of $\mathrm{Bi}$ nanocrystals from unexpected oxidation and could serve as a scatter layer for improving the absorption of NIR light, enabling a high photothermal conversion efficiency $(\sim 43 \%)$ and excellent photostability. It was demonstrated that CQ molecules, delivered intracellularly by $\mathrm{Bi} @ \mathrm{SiO}_{2}$ nanoparticles, significantly weakened the degradation of autolysosomes by lysosome within the tumor cells, inducing clear suppression to autophagy effect. Both in vitro and in vivo anti-tumor effects were promoted by a high magnitude owing to the combined effects achieved by $\mathrm{Bi} @ \mathrm{SiO}_{2}-\mathrm{CQ}$ nanoparticles under milder NIR irradiation conditions. This study therefore indicates a potential PTT platform with superior anticancer efficacy.

\section{AUTHOR INFORMATION}

\section{Corresponding Author}

* E-mail: xiang.li@zju.edu.cn

\section{Notes}

The authors declare no competing financial interest.

\section{ACKNOWLEDGMENT}

This work was financially supported by National Nature Science Foundation of China (51672247), '111' Program funded by Education Ministry of China and Sate Bureau of Foreign Experts Affairs (B16043), Fundamental Research Funds for the Central 
Universities (2019XZZX005-3-01) and Major State Research Program of China (2016YFC1101900).

\section{DATA AVAILABILITY}

The raw date required to reproduce these findings are available to download from [INSERT PERMANENT WEB LINK(s)]. The processed data required to reproduce these findings are available to download from [INSERT PERMANENT WEB $\operatorname{LINK}(\mathrm{s})]$.

\section{REFERENCES}

[1] K. Yang, S. Zhang, G. Zhang, X. Sun, S.T. Lee, Z. Liu, Graphene in mice: ultrahigh in vivo tumor uptake and efficient photothermal therapy, Nano Lett. 10(9) (2010) 331823.

[2] W. Zhang, Z. Guo, D. Huang, Z. Liu, X. Guo, H. Zhong, Synergistic effect of chemo-photothermal therapy using PEGylated graphene oxide, Biomaterials 32(33) (2011) 8555-8561.

[3] K.F. Chu, D.E. Dupuy, Thermal ablation of tumours: biological mechanisms and advances in therapy, Nat. Rev. Cancer 14(3) (2014) 199-208.

[4] A. Li, X. Li, X.J. Yu, W. Li, R.Y. Zhao, X. An, D.X. Cui, X.Y. Chen, W.W. Li, Synergistic thermoradiotherapy based on PEGylated $\mathrm{Cu}_{3} \mathrm{BiS}_{3}$ ternary semiconductor nanorods with strong absorption in the second near-infrared window, Biomaterials 112 (2017) 164-175.

[5] G.C. Li, N.F. Mivechi, G. Weitzel, HEAT-SHOCK PROTEINS, THERMOTOLERANCE, AND THEIR RELEVANCE TO CLINICAL HYPERTHERMIA, Int. J. Hyperthermia 11(4) (1995) 459-488.

[6] E. White, The role for autophagy in cancer, J Clin. Invest. 125(1) (2015) 42-46.

[7] B. Levine, G. Kroemer, Autophagy in the pathogenesis of disease, Cell 132(1) (2008) 27-42.

[8] N. Mizushima, B. Levine, A.M. Cuervo, D.J. Klionsky, Autophagy fights disease through cellular self-digestion, Nature 451(7182) (2008) 1069-1075.

[9] J. Li, N. Hou, A. Faried, S. Tsutsumi, H. Kuwano, Inhibition of autophagy augments 5 -fluorouracil chemotherapy in human colon cancer in vitro and in vivo model, Eur. J. Cancer 46(10) (2010) 1900-1909.

[10] H. Chaachouay, P. Ohneseit, M. Toulany, R. Kehlbach, G. Multhoff, H.P. Rodemann, Autophagy contributes to resistance of tumor cells to ionizing radiation, Radiother. Oncol. 99(3) (2011) 287-292.

[11] M.F. Wei, M.W. Chen, K.C. Chen, P.J. Lou, S.Y.F. Lin, S.C. Hung, M. Hsiao, C.J. 
Yao, M.J. Shieh, Autophagy promotes resistance to photodynamic therapy-induced apoptosis selectively in colorectal cancer stem-like cells, Autophagy 10(7) (2014) 11791192.

[12] Z. Zhou, Y. Yan, K. Hu, Y. Zou, Y. Li, R. Ma, Q. Zhang, Y. Cheng, Autophagy inhibition enabled efficient photothermal therapy at a mild temperature, Biomaterials 141 (2017) 116-124.

[13] P. Codogno, A.J. Meijer, Autophagy and signaling: their role in cell survival and cell death, Cell Death Differ. 12 (2005) 1509-1518.

[14] G. Kroemer, M. Jaattela, Lysosomes and autophagy in cell death control, Nat. Rev. Cancer 5(11) (2005) 886-897.

[15] C.J. Diederich, Thermal ablation and high-temperature thermal therapy: Overview of technology and clinical implementation, Int. J. Hyperthermia 21(8) (2005) 745-753. [16] D. Yoo, H. Jeong, S.H. Noh, J.H. Lee, J. Cheon, Magnetically Triggered Dual Functional Nanoparticles for Resistance-Free Apoptotic Hyperthermia, Angew. Chem., Int. Ed. 52(49) (2013) 13047-13051.

[17] Z. Zhang, J. Wang, C. Chen, Near-infrared light-mediated nanoplatforms for cancer thermo-chemotherapy and optical imaging, Adv. Mater. 25(28) (2013) 38693880 .

[18] X. Wang, J. Zhang, Y. Wang, C. Wang, J. Xiao, Q. Zhang, Y. Cheng, Multiresponsive photothermal-chemotherapy with drug-loaded melanin-like nanoparticles for synergetic tumor ablation, Biomaterials 81 (2016) 114-124.

[19] Y. Chen, L. Wang, J. Shi, Two-dimensional non-carbonaceous materials-enabled efficient photothermal cancer therapy, Nano Today 11(3) (2016) 292-308.

[20] Q. Chen, J. Wen, H. Li, Y. Xu, F. Liu, S. Sun, Recent advances in different modal imaging-guided photothermal therapy, Biomaterials 106 (2016) 144-66.

[21] H. Liu, D. Chen, L. Li, T. Liu, L. Tan, X. Wu, F. Tang, Multifunctional Gold Nanoshells on Silica Nanorattles: A Platform for the Combination of Photothermal Therapy and Chemotherapy with Low Systemic Toxicity, Angew. Chem., Int. Ed. 50(4) (2011) 891-895.

[22] H.K. Moon, S.H. Lee, H.C. Choi, In Vivo Near-Infrared Mediated Tumor Destruction by Photothermal Effect of Carbon Nanotubes, ACS Nano 3(11) (2009) 3707-3713.

[23] X. Zeng, M. Luo, G. Liu, X. Wang, W. Tao, Y. Lin, X. Ji, L. Nie, L. Mei, Polydopamine-Modified Black Phosphorous Nanocapsule with Enhanced Stability and Photothermal Performance for Tumor Multimodal Treatments, Adv. Sci. 5(10) (2018) 1800510.

[24] M. Zhou, R. Zhang, M. Huang, W. Lu, S. Song, M.P. Melancon, M. Tian, D. Liang, C. Li, A Chelator-Free Multifunctional Cu-64 CuS Nanoparticle Platform for Simultaneous Micro-PET/CT Imaging and Photothermal Ablation Therapy, J. Am. Chem. Soc. 132(43) (2010) 15351-15358.

[25] J. Liu, X. Zheng, L. Yan, L. Zhou, G. Tian, W. Yin, L. Wang, Y. Liu, Z. Hu, Z. Gu, C. Chen, Y. Zhao, Bismuth Sulfide Nanorods as a Precision Nanomedicine for in Vivo Multimodal Imaging-Guided Photothermal Therapy of Tumor, ACS Nano 9(1) (2015) 696-707. 
[26] P. Lei, R. An, P. Zhang, S. Yao, S. Song, L. Dong, X. Xu, K. Du, J. Feng, H. Zhang, Ultrafast Synthesis of Ultrasmall Poly(Vinylpyrrolidone)-Protected Bismuth Nanodots as a Multifunctional Theranostic Agent for In Vivo Dual-Modal CT/PhotothermalImaging-Guided Photothermal Therapy, Adv. Funct. Mater. 27(35) (2017) 1702018.

[27] M. Ma, Y. Huang, H. Chen, X. Jia, S. Wang, Z. Wang, J. Shi, Bi2S3-embedded mesoporous silica nanoparticles for efficient drug delivery and interstitial radiotherapy sensitization, Biomaterials 37 (2015) 447-55.

[28] Z. Li, J. Shao, Q. Luo, X.F. Yu, H. Xie, H. Fu, S. Tang, H. Wang, G. Han, P.K. Chu, Cell-borne 2D nanomaterials for efficient cancer targeting and photothermal therapy, Biomaterials 133 (2017) 37-48.

[29] X.D. Zhang, J. Chen, Y. Min, G.B. Park, X. Shen, S.S. Song, Y.M. Sun, H. Wang, W. Long, J.P. Xie, K. Gao, L.F. Zhang, S.J. Fan, F.Y. Fan, U. Jeong, Metabolizable Bi 2 Se 3 Nanoplates: Biodistribution, Toxicity, and Uses for Cancer Radiation Therapy and Imaging, Adv. Funct. Mater. 24(12) (2014) 1718-1729.

[30] A.L. Brown, P.C. Naha, V. Benavides-Montes, H.I. Litt, A.M. Goforth, D.P. Cormode, Synthesis, X-ray Opacity, and Biological Compatibility of Ultra-High Payload Elemental Bismuth Nanoparticle X-ray Contrast Agents, Chem. Mater. 26(7) (2014) 2266-2274.

[31] N. Yu, Z. Wang, J. Zhang, Z. Liu, B. Zhu, J. Yu, M. Zhu, C. Peng, Z. Chen, Thiolcapped $\mathrm{Bi}$ nanoparticles as stable and all-in-one type theranostic nanoagents for tumor imaging and thermoradiotherapy, Biomaterials 161 (2018) 279-291.

[32] X. Zhang, Y. Dong, X. Zeng, X. Liang, X. Li, W. Tao, H. Chen, Y. Jiang, L. Mei, S.S. Feng, The effect of autophagy inhibitors on drug delivery using biodegradable polymer nanoparticles in cancer treatment, Biomaterials 35(6) (2014) 1932-43.

[33] Y. Wang, S. Yin, L. Zhang, K. Shi, J. Tang, Z. Zhang, Q. He, A tumor-activatable particle with antimetastatic potential in breast cancer via inhibiting the autophagydependent disassembly of focal adhesion, Biomaterials 168 (2018) 1-9.

[34] D. Kwon, B.G. Cha, Y. Cho, J. Min, E.B. Park, S.J. Kang, J. Kim, Extra-Large Pore Mesoporous Silica Nanoparticles for Directing in Vivo M2 Macrophage Polarization by Delivering IL-4, Nano Lett. 17(5) (2017) 2747-2756.

[35] B.G. Cha, J.H. Jeong, J. Kim, Extra-Large Pore Mesoporous Silica Nanoparticles Enabling Co-Delivery of High Amounts of Protein Antigen and Toll-like Receptor 9 Agonist for Enhanced Cancer Vaccine Efficacy, ACS Cent. Sci. 4(4) (2018) 484-492.

[36] D.K. Roper, W. Ahn, M. Hoepfner, Microscale heat transfer transduced by surface plasmon resonant gold nanoparticles, J. Phys. Chem. C 111(9) (2007) 3636-3641.

[37] Y.L. Liu, K.L. Ai, J.H. Liu, M. Deng, Y.Y. He, L.H. Lu, Dopamine-Melanin Colloidal Nanospheres: An Efficient Near-Infrared Photothermal Therapeutic Agent for In Vivo Cancer Therapy, Adv. Mater. 25(9) (2013) 1353-1359.

[38] J. Zeng, D. Goldfeld, Y.N. Xia, A Plasmon-Assisted Optofluidic (PAOF) System for Measuring the Photothermal Conversion Efficiencies of Gold Nanostructures and Controlling an Electrical Switch, Angew. Chem. Int. Ed. 52(15) (2013) 4169-4173.

[39] J. Li, J.S. Han, T.S. Xu, C.R. Guo, X.Y. Bu, H. Zhang, L.P. Wang, H.C. Sun, B. Yang, Coating Urchinlike Gold Nanoparticles with Polypyrrole Thin Shells To Produce Photothermal Agents with High Stability and Photothermal Transduction Efficiency, 
Langmuir 29(23) (2013) 7102-7110.

[40] W. Feng, L. Chen, M. Qin, X.J. Zhou, Q.Q. Zhang, Y.K. Miao, K.X. Qiu, Y.Z. Zhang, C.L. He, Flower-like PEGylated $\mathrm{MoS}_{2}$ nanoflakes for near-infrared photothermal cancer therapy, Sci. Rep. 5 (2015) 17422.

[41] Q.W. Tian, F.R. Jiang, R.J. Zou, Q. Liu, Z.G. Chen, M.F. Zhu, S.P. Yang, J.L. Wang, J.H. Wang, J.Q. Hu, Hydrophilic $\mathrm{Cu}_{9} \mathrm{~S}_{5}$ Nanocrystals: A Photothermal Agent with a 25.7\% Heat Conversion Efficiency for Photothermal Ablation of Cancer Cells in Vivo, ACS Nano 5(12) (2011) 9761-9771.

[42] W. Li, J. Liu, D. Zhao, Mesoporous materials for energy conversion and storage devices, Nat. Rev. Mater. 1(6) (2016) 16023.

[43] A. Kuma, M. Matsui, N. Mizushima, LC3, an autophagosome marker, can be incorporated into protein aggregates independent of autophagy: Caution in the interpretation of LC3 localization, Autophagy 3(4) (2007) 323-328.

[44] Y. Cao, Y. Luo, J. Zou, J. Ouyang, Z. Cai, X. Zeng, H. Ling, T. Zeng, Autophagy and its role in gastric cancer, Clin. Chim. Acta 489 (2019) 10-20.

[45] X. Zhu, X. Ji, N. Kong, Y. Chen, M. Mahmoudi, X. Xu, L. Ding, W. Tao, T. Cai, Y. Li, T. Gan, A. Barrett, Z. Bharwani, H. Chen, O.C. Farokhzad, Intracellular Mechanistic Understanding of 2D $\mathrm{MoS}_{2}$ Nanosheets for Anti-Exocytosis-Enhanced Synergistic Cancer Therapy, ACS Nano 12(3) (2018) 2922-2938.

[46] X. Ren, Y. Chen, H. Peng, X. Fang, X. Zhang, Q. Chen, X. Wang, W. Yang, X. Sha, Blocking Autophagic Flux Enhances Iron Oxide Nanoparticle Photothermal Therapeutic Efficiency in Cancer Treatment, ACS Appl. Mater. Interfaces 10(33) (2018) 27701-27711.

[47] X. Wu, Y. Wu, Z. Wang, L. Liu, C. Sun, Y. Chen, C. Wang, A Cascade-Targeting Nanocapsule for Enhanced Photothermal Tumor Therapy with Aid of Autophagy Inhibition, Adv. Healthcare Mater. 7(11) (2018) 1800121.

[48] Y. Zhang, R. Sha, L. Zhang, W. Zhang, P. Jin, W. Xu, J. Ding, J. Lin, J. Qian, G. Yao, R. Zhang, F. Luo, J. Zeng, J. Cao, L.P. Wen, Harnessing copper-palladium alloy tetrapod nanoparticle-induced pro-survival autophagy for optimized photothermal therapy of drug-resistant cancer, Nat. Commun. 9(1) (2018) 4236.

\section{FIGURE CAPTIONS}

Fig. 1. Schematic illustration of photothermal therapy approach using $\mathrm{Bi} @ \mathrm{SiO}_{2}$ nanoparticles loaded with autophagy inhibitor CQ.

Fig. 2. (a) Schematic illustration of the formation of $\mathrm{Bi} @ \mathrm{SiO}_{2}-\mathrm{CQ}$ nanoparticle. SEM and TEM images of $(b, c) \mathrm{SiO}_{2}$ and $(\mathrm{d}, \mathrm{f}) \mathrm{Bi} @ \mathrm{SiO}_{2}$ nanoparticles. (f) STEM and corresponding element mapping images of $\mathrm{Bi} @ \mathrm{SiO}_{2}$ nanoparticles. (g) XRD patterns of $\mathrm{SiO}_{2}$ and $\mathrm{Bi} @ \mathrm{SiO}_{2}$ nanoparticles. (h) XPS spectrum of $\mathrm{Bi} @ \mathrm{SiO}_{2}$ nanoparticles. 
Fig. 3. (a) XRD patterns of $\mathrm{Bi}$ nanoparticles and $\mathrm{Bi} @ \mathrm{SiO}_{2}$ nanoparticles before and after the exposure to air for 4 days. (b) Zeta potential of $\mathrm{SiO}_{2}, \mathrm{Bi} @ \mathrm{SiO}_{2}, \mathrm{CQ}$ and $\mathrm{Bi} @ \mathrm{SiO}_{2}-\mathrm{CQ}$ samples, respectively. (c) UV-vis spectra of $\mathrm{CQ}, \mathrm{Bi} @ \mathrm{SiO}_{2}$ and $\mathrm{Bi} @ \mathrm{SiO}_{2}-$ CQ. (d) DLS measurements of $\mathrm{SiO}_{2}, \mathrm{Bi} @ \mathrm{SiO}_{2}$ and $\mathrm{Bi} @ \mathrm{SiO}_{2}-\mathrm{CQ}$ nanoparticles in water. (e) Temperature elevation of pure water and $\mathrm{Bi} @ \mathrm{SiO}_{2}$ solutions with different concentrations irradiated by an $808 \mathrm{~nm}$ laser $\left(1.0 \mathrm{~W} \mathrm{~cm}^{-2}\right)$ for prolonged time. (f) The real time thermal images of $\mathrm{Bi} @ \mathrm{SiO}_{2}$ solutions under the irradiation by an $808 \mathrm{~nm}$ laser $\left(1.0 \mathrm{~W} \mathrm{~cm}{ }^{-2}\right)$. (g) The photothermal response of $\mathrm{Bi} @ \mathrm{SiO}_{2}$ nanoparticles aqueous solution $\left(400 \mu \mathrm{g} \mathrm{mL}^{-1}\right)$ for $900 \mathrm{~s}$ with an $808 \mathrm{~nm}$ laser $\left(1.0 \mathrm{~W} \mathrm{~cm}^{-2}\right)$. (h) Schematic illustration of scattering of light in the pore of silica. (i) Temperature variation of $\mathrm{Bi} @ \mathrm{SiO}_{2}$ aqueous solutions $(400 \mu \mathrm{g} \mathrm{mL}-1)$ under cyclic irradiation (808 nm NIR, 1.0 $\mathrm{W} \mathrm{cm} \mathrm{cm}^{-2}, 600 \mathrm{~s}, 4$ cycles).

Fig. 4. (a) In vitro cell viability of 4T1 cells incubated with $\mathrm{Bi} @ \mathrm{SiO}_{2}$ nanoparticles at $37^{\circ} \mathrm{C}$ for $12 \mathrm{~h}$ and $24 \mathrm{~h}$ at different concentrations. (b) Viability of 4T1 cells incubated with blank control, $\mathrm{CQ}, \mathrm{Bi} @ \mathrm{SiO}_{2}$ and $\mathrm{Bi} @ \mathrm{SiO}_{2}-\mathrm{CQ}$ samples with and without irradiation by $808 \mathrm{~nm}$ laser $\left(1.0 \mathrm{~W} \mathrm{~cm}^{-2}, 5 \mathrm{~min}\right)$. (c) Viability of $4 \mathrm{~T} 1$ cells incubated with $\mathrm{Bi} @ \mathrm{SiO}_{2}$ and $\mathrm{Bi} @ \mathrm{SiO}_{2}-\mathrm{CQ}$ solutions with different concentration after irradiation by $808 \mathrm{~nm}$ laser $\left(1.0 \mathrm{~W} \mathrm{~cm}^{-2}, 5 \mathrm{~min}\right)$. (d) Viability of 4T1 cells incubated with the blank control, $\mathrm{Bi} @ \mathrm{SiO}_{2}$ and $\mathrm{Bi} @ \mathrm{SiO}_{2}-\mathrm{CQ}$ solutions after irradiation by $808 \mathrm{~nm}$ laser $(1.0 \mathrm{~W}$ $\mathrm{cm}^{-2}$ ) for different time. (e) Fluorescence images of 4T1 cells stained with calcein-AM (green, live cells) and propidium iodide (red, dead cells) after different treatments. The scale bar is $200 \mu \mathrm{m} .{ }^{* *} \mathrm{p}<0.01$ and ${ }^{* * *} \mathrm{p}<0.001$ analyzed by student's t-test.

Fig. 5. (a) Western blot assay for LC-I and LC-II and (b) the expression magnitude of LC-II relative to $\beta$-actin. 4T1 cells were incubated with $\mathrm{Bi} @ \mathrm{SiO}_{2}$ solutions with or without $808 \mathrm{~nm}$ irradiation $\left(1.0 \mathrm{~W} \mathrm{~cm}^{-2}, 5 \mathrm{~min}\right)$. (d) Western blot assay for LC-I and LCII and (e) the expression magnitude of LC-II relative to $\beta$-actin. 4T1 cells were incubated with the blank control, CQ, Bi@ $\mathrm{SiO}_{2}$ and $\mathrm{Bi} @ \mathrm{SiO}_{2}-\mathrm{CQ}$ solutions with 808 $\mathrm{nm}$ irradiation $\left(1.0 \mathrm{~W} \mathrm{~cm}^{-2}, 5 \mathrm{~min}\right)$. (e) Confocal images of 4T1 cells stained by DAPI and LysoTracker Red. (f) Schematic illustration of the mechanism of the photothermal anticancer effect amplified by autophagy inhibition. $* * p<0.01$ and $* * * p<0.001$ analyzed by student's t-test.

Fig. 6. (a) Real time infrared thermal images and b) temperature curves of tumorbearing mice intravenously injected with PBS (control) and $\mathrm{Bi} @ \mathrm{SiO}_{2}$ nanoparticles (33.3 $\left.\mathrm{mg} \mathrm{kg}^{-1}\right)$ under the irradiation by $808 \mathrm{~nm}$ NIR laser $\left(1.0 \mathrm{~W} \mathrm{~cm}^{-2}, 7 \mathrm{~min}\right.$ ). (c-e) Body weight, relative tumor volume and tumor weight in mice after different treatment. (f) Digital photographs of tumors collected at day 14 from different groups of mice. $(\mathrm{g})$ 
H\&E-stained images of tumors from different groups. The scale bar is $100 \mu \mathrm{m} .{ }^{* *} \mathrm{p}<$ 0.01 and $* * * p<0.001$ analyzed by student's t-test.

\section{Figure List}

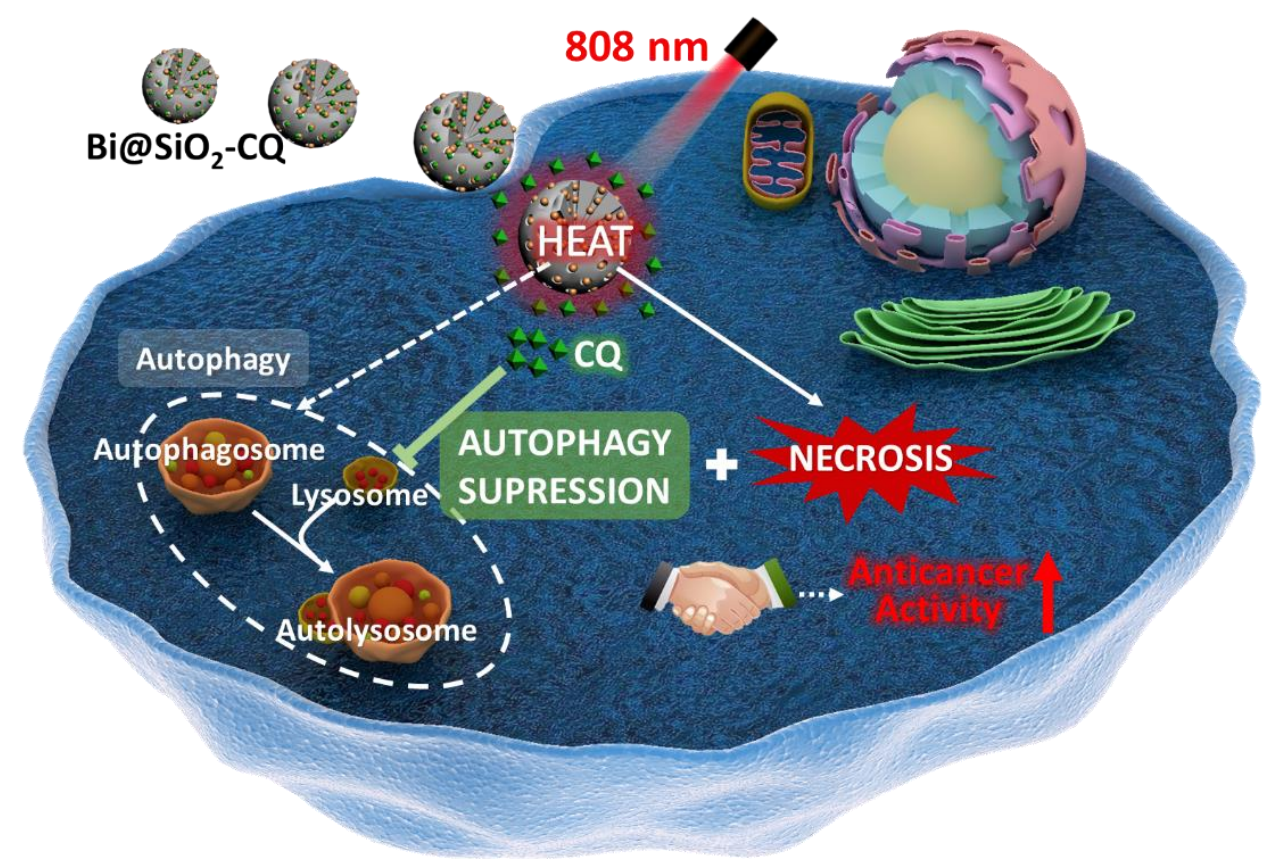

Fig. 1. Schematic illustration of photothermal therapy approach using $\mathrm{Bi} @ \mathrm{SiO}_{2}$ nanoparticles loaded with autophagy inhibitor CQ. 

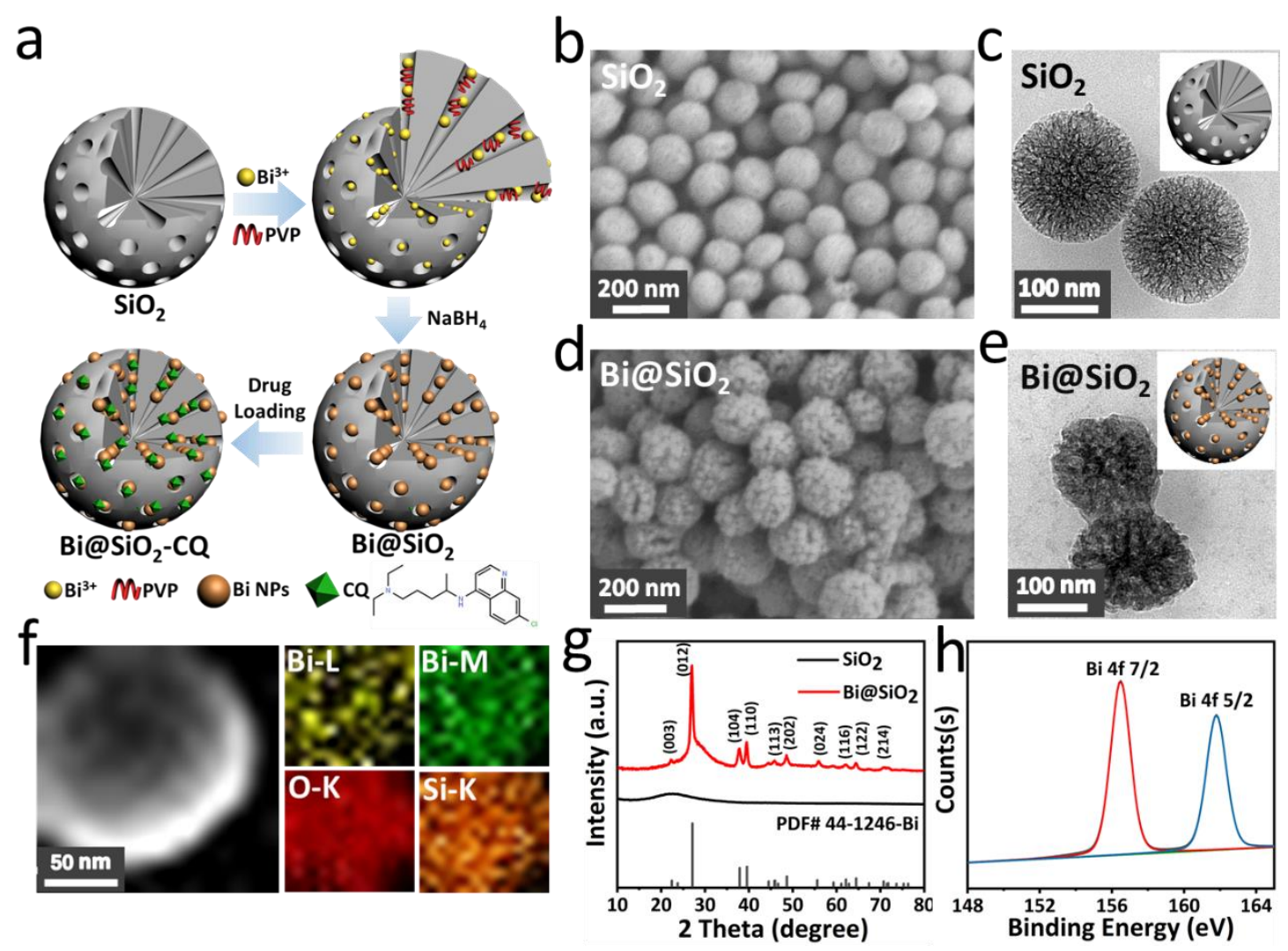

Fig. 2. (a) Schematic illustration of the formation of $\mathrm{Bi} @ \mathrm{SiO}_{2}-\mathrm{CQ}$ nanoparticle. SEM and TEM images of $(b, c) \mathrm{SiO}_{2}$ and (d, f) $\mathrm{Bi} @ \mathrm{SiO}_{2}$ nanoparticles. (f) STEM and corresponding element mapping images of $\mathrm{Bi} @ \mathrm{SiO}_{2}$ nanoparticles. $(\mathrm{g})$ XRD patterns of $\mathrm{SiO}_{2}$ and $\mathrm{Bi} @ \mathrm{SiO}_{2}$ nanoparticles. (h) XPS spectrum of $\mathrm{Bi} @ \mathrm{SiO}_{2}$ nanoparticles. 

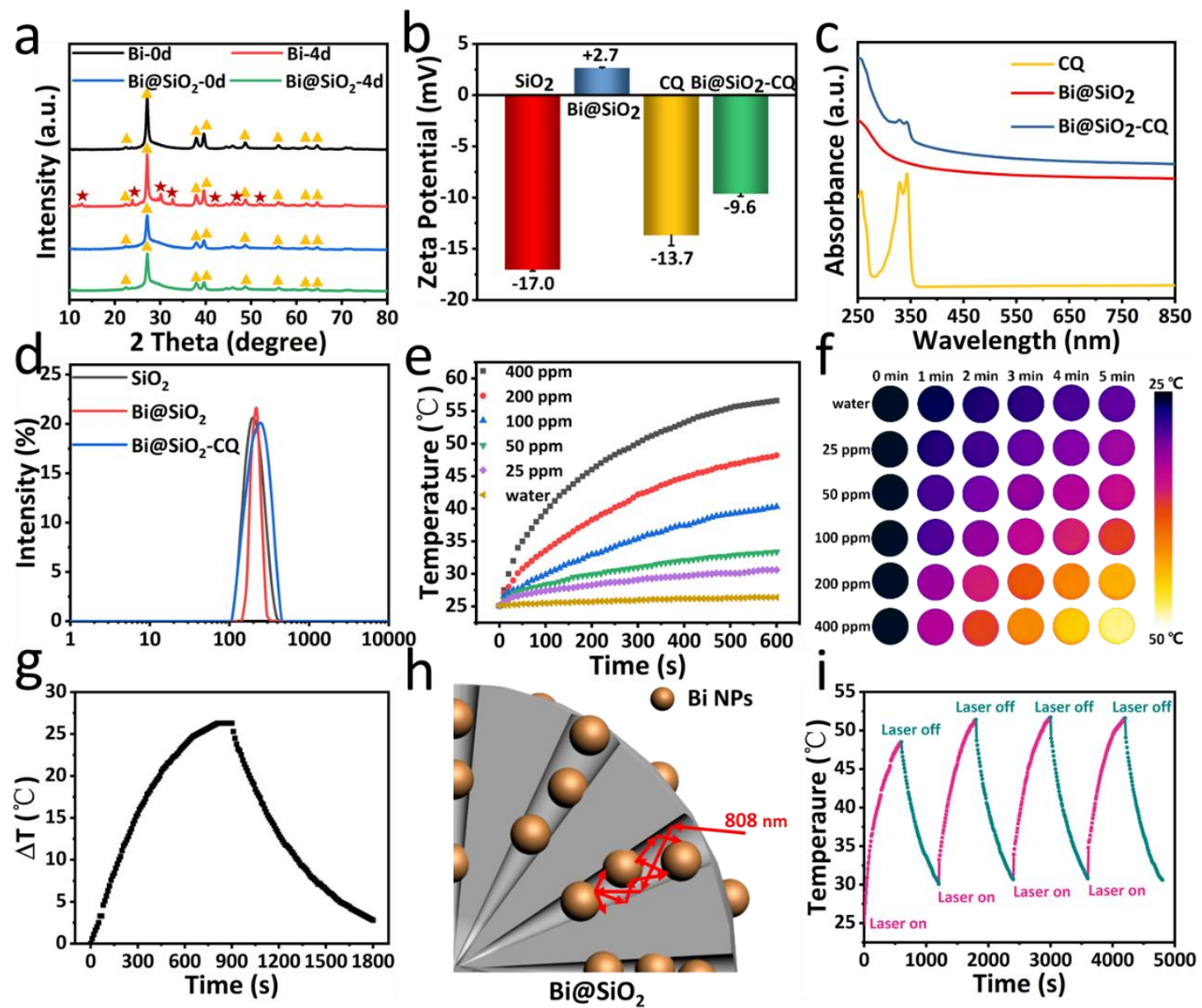

Fig. 3. (a) XRD patterns of $\mathrm{Bi}$ nanoparticles and $\mathrm{Bi} @ \mathrm{SiO}_{2}$ nanoparticles before and after the exposure to air for 4 days. (b) Zeta potential of $\mathrm{SiO}_{2}, \mathrm{Bi} @ \mathrm{SiO}_{2}, \mathrm{CQ}$ and $\mathrm{Bi} @ \mathrm{SiO}_{2}-\mathrm{CQ}$ samples, respectively. (c) UV-vis spectra of CQ, $\mathrm{Bi} @ \mathrm{SiO}_{2}$ and $\mathrm{Bi} @ \mathrm{SiO}_{2}-$ CQ. (d) DLS measurements of $\mathrm{SiO}_{2}, \mathrm{Bi} @ \mathrm{SiO}_{2}$ and $\mathrm{Bi} @ \mathrm{SiO}_{2}-\mathrm{CQ}$ nanoparticles in water. (e) Temperature elevation of pure water and $\mathrm{Bi} @ \mathrm{SiO}_{2}$ solutions with different concentrations irradiated by an $808 \mathrm{~nm}$ laser $\left(1.0 \mathrm{~W} \mathrm{~cm}^{-2}\right)$ for prolonged time. (f) The real time thermal images of $\mathrm{Bi} @ \mathrm{SiO}_{2}$ solutions under the irradiation by an $808 \mathrm{~nm}$ laser $\left(1.0 \mathrm{~W} \mathrm{~cm}{ }^{-2}\right)$. (g) The photothermal response of $\mathrm{Bi} @ \mathrm{SiO}_{2}$ nanoparticles aqueous solution $\left(400 \mu \mathrm{g} \mathrm{mL}^{-1}\right)$ for $900 \mathrm{~s}$ with an $808 \mathrm{~nm}$ laser $\left(1.0 \mathrm{~W} \mathrm{~cm}^{-2}\right)$. (h) Schematic illustration of scattering of light in the pore of silica. (i) Temperature variation of $\mathrm{Bi} @ \mathrm{SiO}_{2}$ aqueous solutions $(400 \mu \mathrm{g} \mathrm{mL}-1)$ under cyclic irradiation (808 nm NIR, 1.0 $\mathrm{W} \mathrm{cm} \mathrm{cm}^{-2}, 600 \mathrm{~s}, 4$ cycles). 

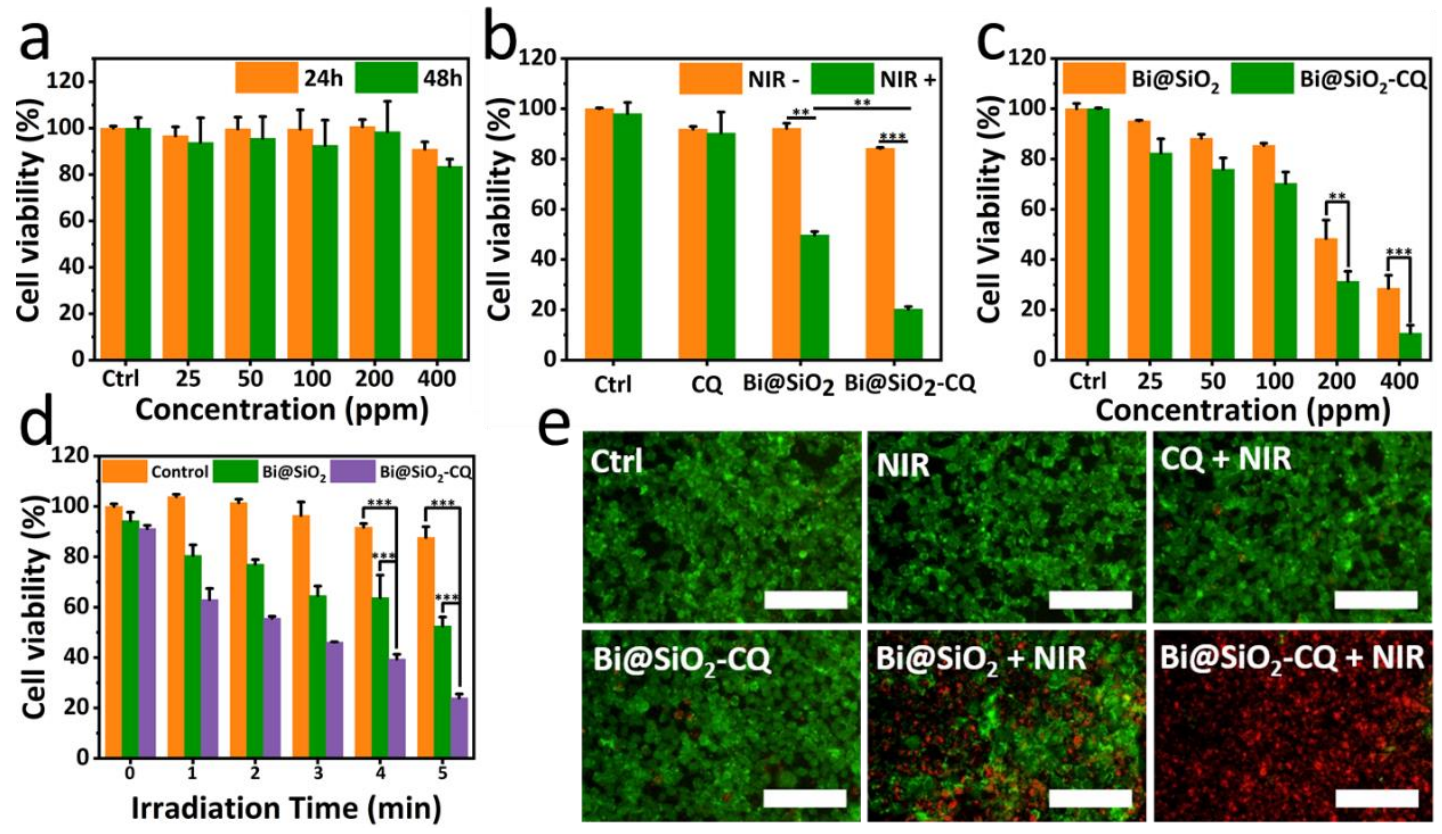

Fig. 4. (a) In vitro cell viability of $4 \mathrm{~T} 1$ cells incubated with $\mathrm{Bi} @ \mathrm{SiO}_{2}$ nanoparticles at $37^{\circ} \mathrm{C}$ for $12 \mathrm{~h}$ and $24 \mathrm{~h}$ at different concentrations. (b) Viability of $4 \mathrm{~T} 1$ cells incubated with blank control, $\mathrm{CQ}, \mathrm{Bi} @ \mathrm{SiO}_{2}$ and $\mathrm{Bi} @ \mathrm{SiO}_{2}-\mathrm{CQ}$ samples with and without irradiation by $808 \mathrm{~nm}$ laser $\left(1.0 \mathrm{~W} \mathrm{~cm}^{-2}, 5 \mathrm{~min}\right)$. (c) Viability of $4 \mathrm{~T} 1$ cells incubated with $\mathrm{Bi} @ \mathrm{SiO}_{2}$ and $\mathrm{Bi} @ \mathrm{SiO}_{2}-\mathrm{CQ}$ solutions with different concentration after irradiation by $808 \mathrm{~nm}$ laser $\left(1.0 \mathrm{~W} \mathrm{~cm}^{-2}, 5 \mathrm{~min}\right)$. (d) Viability of $4 \mathrm{~T} 1$ cells incubated with the blank control, $\mathrm{Bi} @ \mathrm{SiO}_{2}$ and $\mathrm{Bi} @ \mathrm{SiO}_{2}-\mathrm{CQ}$ solutions after irradiation by 808 nm laser $(1.0 \mathrm{~W}$ $\mathrm{cm}^{-2}$ ) for different time. (e) Fluorescence images of 4T1 cells stained with calcein-AM (green, live cells) and propidium iodide (red, dead cells) after different treatments. The scale bar is $200 \mu \mathrm{m} .{ }^{* *} \mathrm{p}<0.01$ and $* * * \mathrm{p}<0.001$ analyzed by student's t-test. 


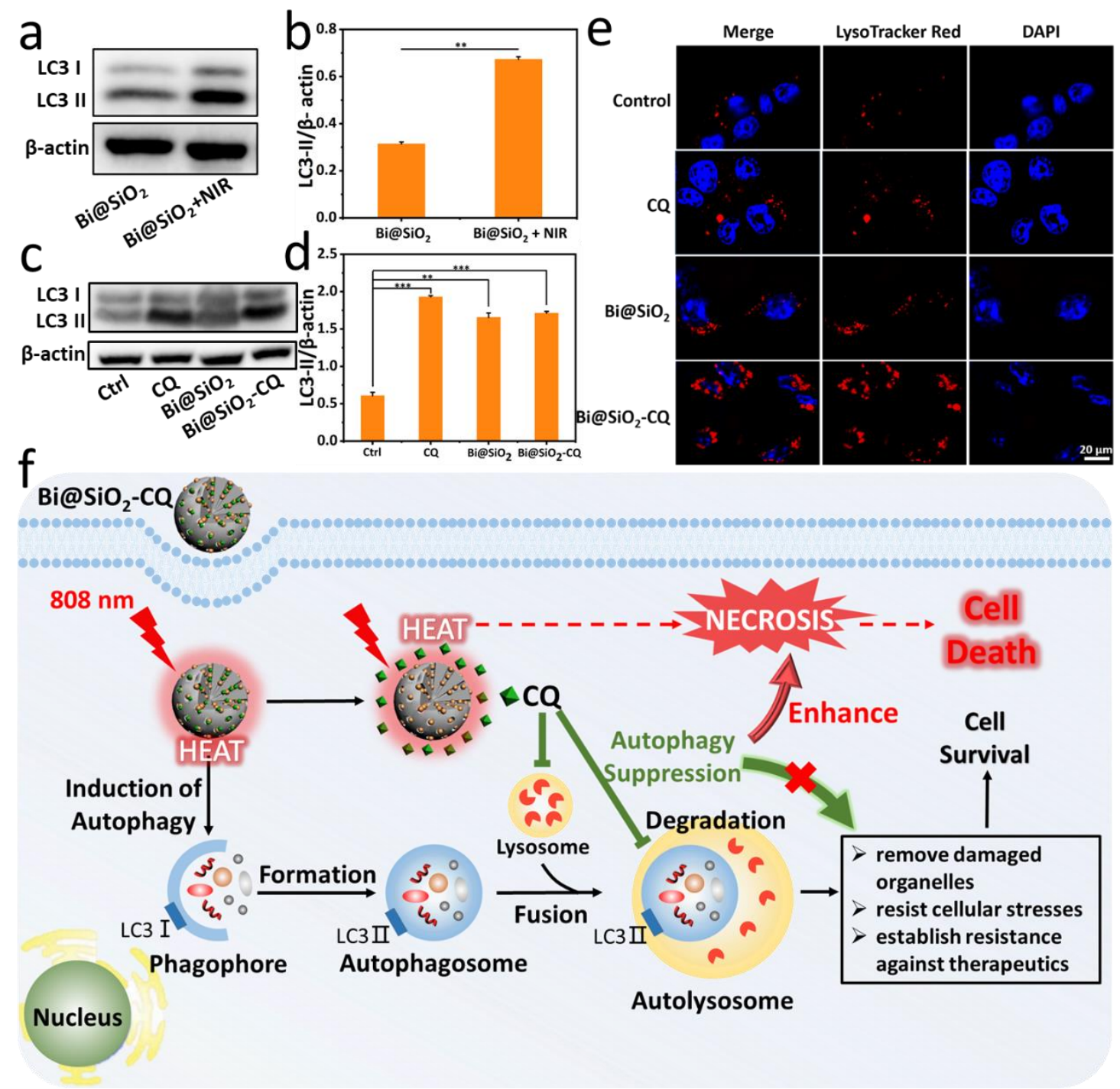

Fig. 5. (a) Western blot assay for LC-I and LC-II and (b) the expression magnitude of LC-II relative to $\beta$-actin. 4T1 cells were incubated with $\mathrm{Bi} @ \mathrm{SiO}_{2}$ solutions with or without $808 \mathrm{~nm}$ irradiation ( $\left.1.0 \mathrm{~W} \mathrm{~cm}^{-2}, 5 \mathrm{~min}\right)$. (d) Western blot assay for LC-I and LCII and (e) the expression magnitude of LC-II relative to $\beta$-actin. 4T1 cells were incubated with the blank control, CQ, $\mathrm{Bi} @ \mathrm{SiO}_{2}$ and $\mathrm{Bi} @ \mathrm{SiO}_{2}-\mathrm{CQ}$ solutions with 808 $\mathrm{nm}$ irradiation $\left(1.0 \mathrm{~W} \mathrm{~cm}^{-2}, 5 \mathrm{~min}\right)$. (e) Confocal images of $4 \mathrm{~T} 1$ cells stained by DAPI and LysoTracker Red. (f) Schematic illustration of the mechanism of the photothermal anticancer effect amplified by autophagy inhibition. $* * p<0.01$ and $* * * p<0.001$ analyzed by student's t-test. 

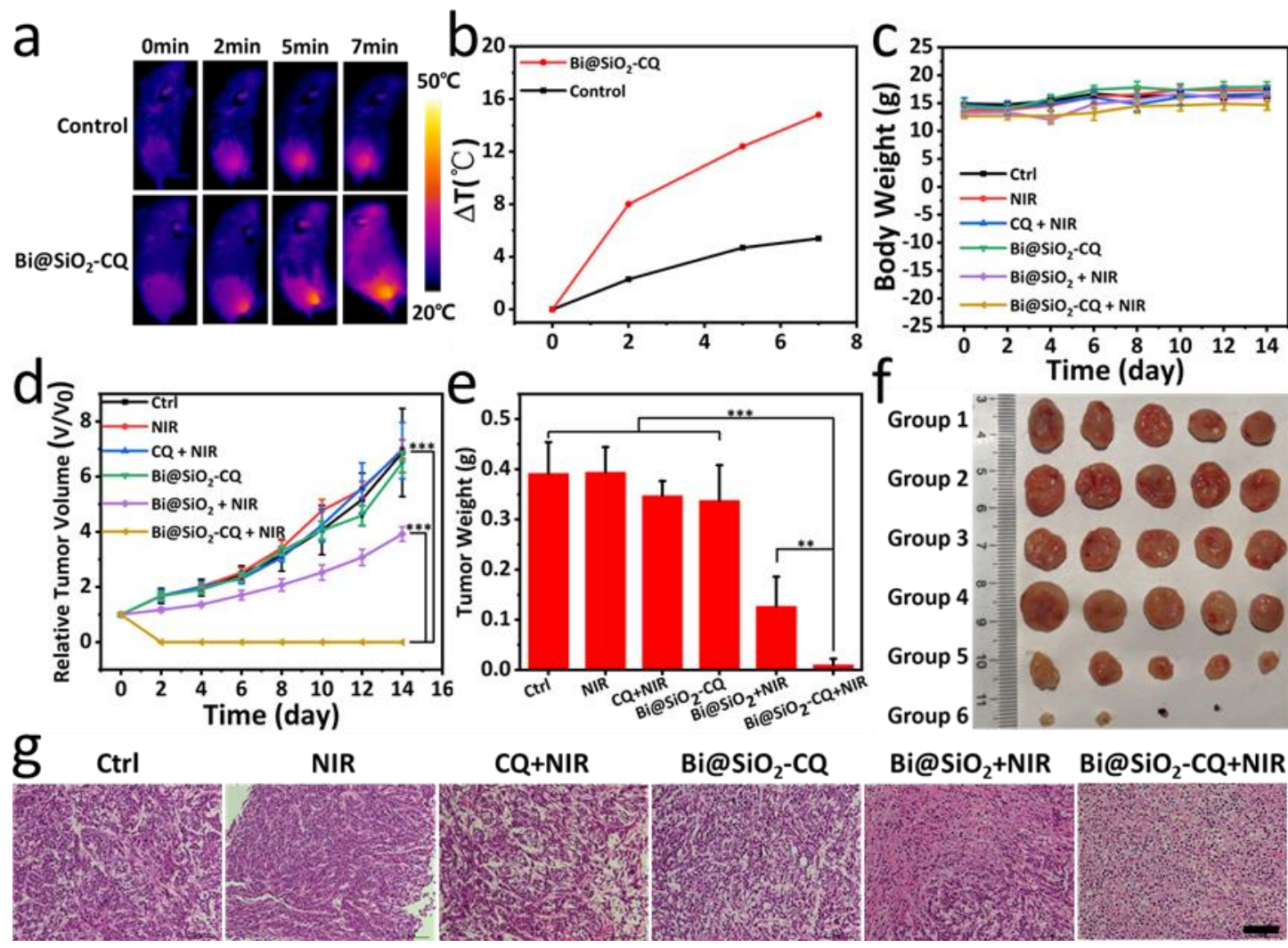

Fig. 6. (a) Real time infrared thermal images and b) temperature curves of tumorbearing mice intravenously injected with PBS (control) and $\mathrm{Bi} @ \mathrm{SiO}_{2}$ nanoparticles (33.3 $\left.\mathrm{mg} \mathrm{kg}^{-1}\right)$ under the irradiation by $808 \mathrm{~nm}$ NIR laser $\left(1.0 \mathrm{~W} \mathrm{~cm}^{-2}, 7 \mathrm{~min}\right)$. (c-e) Body weight, relative tumor volume and tumor weight in mice after different treatment. (f) Digital photographs of tumors collected at day 14 from different groups of mice. (g) H\&E-stained images of tumors from different groups. The scale bar is $100 \mu \mathrm{m} .{ }^{* *} \mathrm{p}<$ 0.01 and $* * * p<0.001$ analyzed by student's t-test. 